\section{New law in effect at last}

\section{from our special correspondent}

\section{Barcelona}

THE Spanish parliament has at last approved the science law which the government has been preparing for several months. But even now, it is far from clear what the effects of the new framework will be, although the fact that the law, called the Ley de Fomento y Coordinación General de la Investigación Científica y Técnica, is the first to have brought research within a general framework cannot but be significant.

The new framework will include all major research institutes in Spain. No fewer than ten ministries of the government will be involved in the operation of the law, together with representatives of several autonomous regions. While the law itself does not define research as a national priority, one of the first of the tasks required within the new framework will be the preparation of a national plan for scientific research and technical development.

As part of the new development, it has also been agreed that the budget of the principal organization for the support of scientific research, the Comisión Asesora de Investigación Científica y Técnica (CAICYT) will probably be increased in the current year by about 36 per cent above that for 1985, when CAICYT had 9,112 million pesetas (roughly $\$ 60$ million) to spend.

CAICYT at present spends money on research grants in universities and by means of joint ventures with industrial companies and other organizations. The trend begun by the centrist government of 1981-82 of designating certain areas of research for special attention, and which has been reinforced by the present socialist government, is likely to be continued, with special attention being paid to research in biotechnology, aquaculture, agroenergetics, microelectronics and high-energy physics, which last year accounted for nearly a quarter of total spending.

In general, however, the new law is permissive only, which means that the amounts of money available in future years, and the numbers of posts that will be created within the new framework, are at present unspecified. Moreover, the composition of the key advisory committee, the Consejo Asesor, is for the time being undefined, although the government says that the composition of the committee will be decided in the next three months. Much will depend on the balance in the membership of the new council between working scientists, industrialists, administrators and government officials. But the provision for better coordination between the ministries of in-

\section{China}

dustry and of education and science is welcome, while much is expected from the improved interaction between the public and private sectors.

General reactions towards the new law so far are mixed. The measure has been criticized by some for its neglect of questions such as the proper relationship between the central and the regional governments. Professor A. Nieto, a former president of the Spanish research council (CSIC) has for example pointed out that the Catalan legislation that gives the regional government "exclusive competence" within its territory is potentially a source of confusion. F. Mayor, previously a minister of education and science in the centrist government of the early $1980 \mathrm{~s}$, would have preferred that the evolution of Spanish science should be more closely determined by the creative energies of scientists than by planning, to which the new law will give new encouragement.

Others point out that there is nothing in the new law to encourage the application of the process of peer-review not merely to the assessment of research grants but to the evaluation of the work of university departments and research institutes, where the influence of foreign scientists is still conspicuous by its absence.

On balance, the new law is a step in the right direction, although the development of science in Spain will be more directly determined by the practical decisions taken by the government about the budget for research and the appointment of people to the key posts within the new administrative framework. Certainly there is nothing in the new law to guarantee that the social status of Spanish science will in future be enhanced, nor is there an audible echo of the positive commitment to science by President Francois Mitterrand at the outset of his socialist government of France in 1981.

\title{
Educational reforms ahead
}

China has published a census of its civilian science and technology sector, the first of its kind since 1949. It shows that the country has 4,690 civilian research institutes, employing more than 770,000 people, including 231,000 scientists and engineers and 121,000 technicians. There are 760 universities and colleges of science, technology, agriculture and medicine, with a "technical work-force" of 481,088 , including 356,088 scientists and engineers. Both the institutes and the universities and colleges are deeply involved in work for industry: in 1985, the institutes earned 780 million yuan by developing technology for industrial enterprises, while the universities signed 7,077 contracts with industry worth a further 126.4 million yuan.

Nevertheless, official approval of the links between research and industry is by no means unqualified. Speeches at a meeting of the new State Education Commission last month suggested that the relationship between the study of basic science and its application in the development of technology is not being "handled correctly". To produce a "rational structure of personnel", it was urged, higher schools should coordinate their efforts to avoid duplication. Schools of engineering, therefore, should concentrate in applying science to technological development, and colleges of science should concentrate on basic research "while also engaging in the development of technology". For those unable to study full-time, the planned television open university should enrol not only people already in a job but also middle-school leavers.
Educational reforms scheduled for this year, it was indicated, will be aimed at eliminating the egalitarianism persisting from the period of the cultural revolution ("everyone eating from the same big pot"), to which the current leadership is resolutely opposed. A pilot scheme involving a few universities and colleges will be launched this year by which student grants will be replaced by a system of scholarships to "harness the initiative of students and their conscientiousness in study, and to reward those who are both academically promising and morally outstanding".

A new system for doctoral dissertations and the conferment of doctorates in various fields including clinical medicine and engineering is to be worked out. Now that many colleges and universities have established postgraduate courses, postgraduate training should be concentrated mainly in China itself, the commission urged, and only "units in need of specialized personnel" should send students abroad. Foreign study tours by trained personnel will however continue to be encouraged as part of the policy of opening China up to the outside world.

An interesting feature of China's recent policy on foreign study is the practice of allowing certain people to study abroad at their own expense. This policy will also continue but it was urged that such people should be treated in the same way as those who study abroad at the government's expense and that they should be offered "correct guidance" to overcome the "problems and defects" that now exist among them.

Vera Rich 